\title{
Did the medieval philosophers admit the identity principle as prior to the principle of non-contradiction?
}

Os filósofos medievais admitiam o princípio de identidade como primeiro ao princípio de não contradição?

Ana Rieger Schmidt ${ }^{1}$

\begin{abstract}
The present article deals with the not very common opinion among medieval philosophers according to which the identity principle (ens est ens) is the true first principle, undermining the primacy of the principle of non-contradiction. Following a refutation of this position in the logical work of the Franciscan Geraldus Odonis, we intend to investigate its target as well as other cases of the same dispute in 14th century authors: Antoine Andre, John of Buridan, John of Baconthorpe and Nicolas of Autrecourt. We defend that Odonis presents a successful response to this position.

Key-words: principle of non-contradiction, identity, logic, Geraldus Odonis, Antoine Andre, John of Buridan, John of Baconthorpe, Nicolas of Autrecourt.
\end{abstract}

Resumo: Este artigo aborda uma opinião pouco comum entre os filósofos medievais, segundo a qual o princípio de identidade (ens est ens) é o verdadeiro primeiro princípio, enfraquecendo a primazia do princípio de não-contradição. Seguindo uma refutação dessa posição na obra lógica do franciscano Geraldo Odonis, pretendemos investigar seu alvo, além de outros casos da mesma disputa em autores do século XIV: Antônio André, João de Baconthorpe e Nicolás de Autrecourt. Defendemos que Odonis apresenta uma resposta satisfatória à posição mencionada.

Palavras-Chave Palavras chave: Princípio de não-contradição, identidade, lógica, Geraldo Odon, Antônio André, João de Baconthorpe e Nicolás de Autrecourt.

Medieval philosophers and theologians inherit a principle of Aristotelian origin that expresses the limits of meaning and consists in the first certain knowledge. It is up to the first philosopher or metaphysician (the one who investigates being qua being) to identify the most fundamental principle of all: the principle that stems from being taken in itself. Only from the fact that it is the most fundamental principle, we can say that it must satisfy some conditions ${ }^{2}$ : (i) it must be such that no one can be deceived about it, would be incompatible with a secure knowledge of being as a being (it is, therefore, notissimum); (ii) it cannot be

\footnotetext{
${ }^{1}$ Doutora, Professora de Filosofia Medieval - UFRGS, Porto Alegre

${ }^{2}$ Aristotle, Metaphysics, book Gamma, ch. IV.
} 
hypothetical because one only takes something as a hypothesis when she does not yet have a certain knowledge of it. Moreover since it is the very first principle, there would be nothing that we could use to prove this hypothesis (it is, therefore, firmissimum); (iii) it cannot be demonstrated, otherwise it would entail a petition of principle, since every demonstration recurs to him, even if it does not use it as an explicit premise (it is, therefore. certissimum).

That said, the first principle is stated: it is impossible for the same attribute to belong and not belong to the same subject under the same respect and at the same time. This formulation was later known as the principle of non-contradiction (PNC). It is clear to Aristotle that the PNC does not require proof, but despite having the characteristics described above, some deny it by means of lack of education. However, Aristotle believes that opponents of the PNC can be convinced otherwise if we show them the difficulties involved in refusing the PNC. In effect, Aristotle is led to formulate a differentiated strategy to defend the first principle: he does not demonstrate it in a strict sense, but operates a "reversal" in the order of the demonstration: he does not show to the adversary something that he does not know, but on the contrary, it is shown precisely that he already knows in some way the principle in question, in the sense that he necessarily observes it - even as you refuse your truth.

Thus, in order to reply to the possible adversaries to the first principles, that is, those who claim to deny its validity, Aristotle shows that contradiction is the annihilation of all meaningful speech ${ }^{3}$. This principle cannot be denied without being observed at the same time. A similar, but much less explored argumentation is found to defend the unrestricted validity of the principle of excluded middle: of two contradictory propositions one must be true, and the other false. Any principle of such primacy belongs to the supreme science of metaphysics - first in the hierarchy of sciences.

The principle of non-contradiction receives various formulations in the medieval texts, such as impossibile eidem simul inesse et non inesse idem, impossibile sit simul esse et non esse, or in its coupled form with the principle of the excluded middle: de quolibet esse vel non esse et de nullo

\footnotetext{
3 Aristote, Metaphysics, 1006a11-1007a2o for the principle of non-contradiction; 1008a2-b1o for the principle of excluded middle .
} 
simul. As one would expect, Aristotle's first principles were largely accepted among medieval thinkers. There was no reason (and there could not be one) to question it primacy. Still, we can find some interesting cases of arguments undermining PNC's absolute priority in $14^{\text {th }}$ century authors. Giraldus Odonis's 1320's treatise on the First principles of sciences ${ }^{4}$ first brought my attention to this issue. As the larger and most complete medieval discussion on the first principles, Odonis deals extensively with their main features, as their truth, their indemonstrability, their necessity, their universality and, naturally, their primacy. Most of the arguments are meant to present Odonis' quite original position - the principles of noncontradiction and excluded middle are properly logical (and not metaphysical, as traditionally claimed) due to their maximum scope, identical with the realm of intelligible objects (including both real being and beings of reason), but we do find him taking part in minor debates and refuting a number of problematic opinions. Precisely when Odonis is explaining the primacy of both principles he concentrates on giving a response to a surprising position (that I believe we can attribute to Antoine Andre, as we will see), according to which the PNC specially is not absolutely prior; instead, another principle, more simple and immediate to our reasoning is to receive that status: being is being (ens est ens). Indisputably, the principle that states the identity of being to itself is much more straightforward and uncomplicated, but is it prior? I shall proceed to Odonis` treatment of this issue in order to fully set this debate.

\section{Formal primacy and cognitive primacy}

We find in Odonis treatment of the primacy of first principles a twofold distinction: we can consider the principles cognitive primacy or their formal primacy. Concerning the first kind, Odonis focuses on the priority of the notion of being in the order of knowledge. I do not intend to develop this matter in here; it should be sufficient to describe de general reasoning and key theses. Odonis takes up the triple scotistic distinction ${ }^{5}$ of the priority of the object of the intellect to show that the first principles are

\footnotetext{
${ }^{4}$ Giraldus Odonis O.f.m. Opera Philosophica, Vol. I : Logica, De principiis scientiarum. ed. L.M. de Rijk. Leiden: Brill, 1997.

${ }^{5}$ Cf. John Duns Scot, Ordinatio I, 3, § 69, ed. Vaticane, Vol. III.
} 
formed from the first object of the intellect according to the adequacy criterion. He therefore identifies the subject of the first principles with the first object of the intellect while disassociating it from the proper subject of Metaphysics. Aristotle's first principles are, in fact, logical, for they do not deal exclusively nor specially with real being and substances, but are even more universal and encompassing: they belong to the domain of intelligibility and rule every action of thinking and signifying ${ }^{6}$.

Concerning formal primacy, Odonis responds to objections that find in the complexity of the formulations "quodlibet esse vel non esse" and "de nullo esse et non-esse" a reason for denying the primacy of these principles, for being first means being the simplest ${ }^{7}$. According to this objection, an absolute simple proposition cannot have a negative particle, nor a disjoint predicate (esse vel non esse) or coupled one (esse et non esse). A simpliciter prime proposition is a categorical affirmation consisting of a single subject and a single predicate united by a noncomplex copula.

In response to this kind of objection the forma enuntiativa of the principles is analyzed. Odonis recognizes that the first principles are not an affirmation nor a negation in an absolute sense (simpliciter): the principle of the excluded middle possesses a "disjunctive verbal copula" (habet copulam verbalem disiunctam) of a composition and a division, while the principle of non-contradiction has a "copulated verbal copula" (habet copulam verbalem copulatam) of a composition plus a division; the negation preceding the copula (not simul) does not apply to its totality, but to each particle, affirmative (esse) and negative (non esse) ${ }^{8}$.

After recognizing the formal elements present in each principle, a distinction is made: one can speak of simplicity in relation to words

\footnotetext{
${ }^{6}$ Giraldus Odonis, De principiis scientiarum, VI, §19-23, p. 426-28.

${ }^{7}$ Giraldus Odonis, De principiis scientiarum, VI, §2, p.422: Primo sic obicitur. Quecumque propositio simpliciter prima in genere propositionum est simplex in genere propositionum, idest subiecti simplicis, predicati simplicis, copule simplicis; patet, quoniam ante quamcumque non-simplicem est aliqua alia simplex. Sed hec principia non sunt simplicis copule nec, per consequens, sunt simplices cathegorice. Ergo non sunt propositiones simpliciter prime. Minos patet per capitulo secundo supra.

${ }^{8}$ Giraldus Odonis, De principiis scientiarum, II, §31, p.373: Septima conclusio probatur sic. Principium disiunctum, istud scilicet 'quelibet res est vel non est quelibet res' habet copulam verbalem disiunvtam ex compositione et divisione, pro quarum qualibet indifferenter verificari potest. Ergo nec simpliciter affirmativa nec simpliciter negativa est. principium autem copulatum habet copulam verbalem copulatam ex compositione et divisione, et ex affirmatione et negatione, et cum hoc habet negationem precedentem huiusmodi copulam; et tunc hec negatio precedens vel operatur circa particulam affirmativam, et tunc facit negationem ; vel operatur circa particuam negativam, et tunc facit affirmationem [...].
} 
(quantum ad voces) or one can speak of simplicity in relation to what is stated (quantum ad sententiam). According to the first criterion the principles of non-contradiction and excluded middle are complex and cannot be called first; according to the second criterion, on the other hand, they are absolutely first, insofar as they do not establish a predication, but show the logical possibilities of predication ${ }^{9}$. This can be better understood as a difference between 'to say more' and 'to say less'. For example, to say 'this line is straight', is to say more than 'this line is either straight or curved'. In the first example a claim is made; in the second example we say less than the claim above, for it is not decided whether the line is straight or curved, but only that it must be either straight or curved, which possibility is the case remains indeterminate ${ }^{10}$. Neither the principle of non-contradiction nor that of the excluded third state a claim: they simply pose the limits inside which a claim can be given. From this reasoning, the principle of excluded middle is equally first to the principle of noncontradiction. However, a second group of objections calls into question the existence of two absolutely first principles: it could be objected that there is a dependence between the principle of non-contradiction and that of the excluded. Now, it seems that the truth of disjunction is dependent on the truth of at least one of the disjoints composing it; thus, the principle of the excluded middle depends on the truth of the principle of noncontradiction $^{11}$. On the other hand, it seems that disjunctions are prior to conjunctions, for one can infer a disjunction of a conjunction, but not the opposite: $(\mathrm{x} \& \mathrm{y}) \rightarrow(\mathrm{x} v \mathrm{y})^{12}$.

\footnotetext{
${ }^{9}$ Giraldus Odonis, De principiis scientiarum, VI, §15, p. 425. Cf. also chapter II, §29, p.373.

${ }^{10}$ Giraldus Odonis, De principiis scientiarum, VI, §16, p. 425: Dicendo 'linea est recta' et 'linea est recta vel curva', prima istarum propositionum est simplicior et prior vocaliter, quia sic pauciora includit; secunda vero est simplicior et prior sententialiter, quia minus enuntiat de linea quam prima, quia tantum enuntiat de linea illud quod est commune ad rectitudinem et curvitatem sine differentia huius vel illius. Prima vero enuntiat amplius, quia enuntiat illud idem commune inclusum essentialiter ad rectitudinem et cum hoc differentiam quam addit rectitudo supra illud commune.
}

\footnotetext{
${ }^{11}$ Giraldus Odonis, De principiis scientiarum, VI, §8, p.423: « Septimo quia: Propositio primo vera est independenter vera. Sed hec principia non sunt independenter vera. Probatio quia: Sicut disiunctiva ypotetica est dependenter vera, quia verificatur ad ceritatem alteriusque cathegoricatum ex quibus componitur, et copulativa ad veritatem utruisque, sic ista 'Sortes est, vel non est, albus' verificatur ad veritatem alterutriusque istarum: 'Sortes est albus' vel huius 'Sortes non est albus' ».

${ }^{12}$ Giraldus Odonis, De principiis scientiarum, VI, §12, p.424: « Decimo quia videtur principium disiunctum esse prius copulato [...] quia prius est illud a quo non convertitur subsistendi consequentia; copulatio enim infert disiunctionem, non converso ».
} 
According to Odonis the two principles are equally first and irreducible to each other. These formal objections are all based, says Odonis, on a double confusion: (i) a confusion between what the principles state and the form bay which they state, and (ii) on the twofold nature of contradiction. The first principles are not mere disjunctions nor mere compositions - they give precisely the rules for such. If it is true that a disjunctive proposition depends on the truth of the disjoints, this is not the case with the principle of the excluded middle, for it expresses the necessity of the entire disjunction, and not the truth of each disjoint. Secondly, the contradiction is governed by two irresolvable laws: the impossibility that contradictories are false at the same time (which is expressed by the principle of excluded middle) and the impossibility that contradictions are true at the same time (which is expressed by the principle of non-contradiction). They are both first and independently first. This "binary" character of the first principles is due to the very nature of the contradiction, which involves this double impossibility.

\section{« Ens est ens » is not the first principle}

These considerations provide the key elements to answer to the objection according to which the proposition "ens est ens" would be first to the principles of non-contradiction and excluded middle. Since it has a simpler formulation and the predicate is immediately contained in the subject (they are identical), it should be concluded that this is the true first principle. Odonis's answer to this reasoning is based precisely on the distinction made earlier between "to say more" and "to say less" in a proposition.

'Ens est ens' is an affirmation which expresses a determined predication. Even if Odonis concedes that it is immediate, for it is "analytic" (i.e. the subject is immediately included in the subject), he considers that the principles of non-contradiction and excluded middle remain first because of the indeterminate nature of their predicates. According to Odonis, the determination implied in the copula decides its primacy: the copula presented in the proposition 'ens est ens' is more determined that the disjunction 'esse vel non esse' or the conjunction 'non esse and non-esse'. For this reason, the predicate of the principles of noncontradiction and excluded middle apply to all that can be a subject in a 
proposition without positing it. Whereas the predicate of "ens est ens" is immediately contained in the subject, it depends on the subject being posited, so that the predicate may follow ${ }^{13}$.

Thus, it is not enough that a principle is a simple copula and is necessarily true to be first: we must also ensure that the predicate is indeterminate. The first principles owe their status to the indeterminacy of their subjects and their predicates ('quolibet' supposes for everything one can think of) and of their formulation as a whole. The proposition ens est ens does not precedes the necessity of non-contradiction, but it presupposes it.

The proposition "ens est ens" is clearly seen as necessary due to the inclusion of the predicate in the subject. From this one might think that it expresses the proper nature of predication and must therefore be accepted as the first identity principle. Nevertheless, Odonis does not understand it in this way: the copula in the formula "ens est ens" is the same as in "Sortes est Sortes", "homo est homo" and "chimera est chimera". Indeed, the proposition "ens is ens" is not seen by Odonis as an identity principle, but rather the expression of the fact that the being is identical to itself. In this sense, the copula is the true "principle of identity", whereas "ens est ens" signifies only a determined claim, a specific proposition. Of course, this is an immediate and necessary proposition (per se nota), but it is only another one among others. As a result, "ens est ens" is not considered more fundamental than the principles of non-contradiction and excluded middle. The status first principle remains reserved for the two Aristotelian principles.

\section{The identity principle in Antoine Andre}

Why does Odonis bother answering this objection? It is very likely that he is criticizing the position of a famous disciple of John Duns Scotus: Antoine Andre $\left(\dagger\right.$ 1320). In his commentary on Metaphysics ${ }^{14}$, Andre

\footnotetext{
${ }^{13}$ Gérard Odon, Logica, III, cap. VI, §33, p. 432: « [...] dico quod hec 'ens est ens’ non est prior hiis principiis. Cuius ratio est quia sententia eius est determinatior quam sententia horum principiorum, quoniam esse absolute est magis determinatum quam hoc quod doco 'esse vel non esse'. Et cum dicitur quod illa immediate continetur in subiecto, concedo. Sed ex hoc non sequitur prioritas nisi respactu propositionum mediate contentarum in eo. Hec autem principia magis sunt prima ex natura predicati determinantis sibi omne quod potest esse subiectum cuiuscumque propositionis quam ex natura subiecti quod determinat sibi unde predicatum tenet ».

${ }^{14}$ Antonius Andreae, Quaestiones subtillissimae super duodecim libros Metaphysicae Aristotelis, ed. Venetiis 1491, q. 4 [sans numération de page]: «Vtrum istud principium : 'impossibile est idem simul esse et non esse' sit
} 
argues that the proposition 'omne ens est ens' is the prior to the principle of non-contradiction. It should be noted that this commentary, supposedly a revised edition of the Quaestiones to the Metaphysics of his master, was very successful and is possibly the main channel of the transmission of Duns Scotus' commentary to the Metaphysics ${ }^{15}$.

In the fourth question of his commentary, Andre accepts Aristotle's assertion that the principle "impossibile is idem simul esse et non esse" is the most certain (firmissimum). Yet, it is not to be considered the absolutely first principle (simpliciter primum) because only "omne ens est ens" can be so - which is certainty an innovation in comparison with the more traditional views we find in the commentaries of Thomas Aquinas and Duns Scotus, for example. Andre seems to dissociate the criteria of unconditionally and primacy: a principle may well be unconditional, that is, not be known by means of other proposition, without being truly first. The conditions which must be fulfilled by the most certain principle, namely ${ }^{16}$, (i) no one can be mistaken about it (non contingit circa ipsum dubitari), (ii) it is not conditional (non est conditionale), and (iii) it must necessarily be present in the mind (necesse est venire in mentem) of those who know its terms, are detached from its special priority. Thus, the principle of non-contradiction meets the three conditions without being absolutely first.

Andre's argument to show the priority of his aspirant principium simpliciter primum is based on the claim that the absolutely first principle cannot be analyzed into simpler terms. However, the principle of noncontradiction is overly complex: firstly, it is preceded by the "impossible" modal; in addition, the subject term "idem" is a relative concept (respectivus) and its predicate "esse et non esse" is composed of an

\footnotetext{
firmissimum et notissimum; et q. 5: Vtrum hoc principium : 'impossibile est idem simul esse et non esse' simpliciter sit primum ». Cf. Goris W. "The Foundation of the Principle of Non-Contradiction. Some Remarks on the Medieval Transformation of Metaphysics ». Documenti e studi sulla tradizione filosofica medievale 22, 2011, p. 527-557.

${ }^{15}$ There are 44 manuscrits of Andre's commentary, and 21 printed editions from 1471 and 1523 . Cf. Pini, G. Scotistic Aristotelianism: Antonius Andreas' Expositio and Quaestiones on the Metaphysics, in: Via Scoti. Atti del Congresso Scotistico internazionale, Roma 9-11 marzo 1993, Sileo, L. (éd.) vol. 1, Roma: Edizioni del Pontificio Ateneo Antonianum, 1995, p. 384 .

${ }^{16}$ Antonius Andreae, Quaestiones subtillissimae super duodecim libros Metaphysicae Aristotelis, ed. Venetiis 1491, q. 4.
} 
affirmation and a negation. Now, all that is complex is, by definition, analyzable to the elements which compose it $^{17}$.

Thus, the search for a principle formed of primitive terms led Andre to consider the principle "omne ens est ens", as even more fundamental than the PNC of Aristotle ${ }^{18}$. This "identity principle" is, on one hand formed of the first adequate object of the intellect "ens" is in fact the first term in the ordination of things and the last term in the via resolutionis and, on the other hand, the predicate is immediately included in the subject - because of the identity of the extremes (identitas extremorum). Theses features make the affirmation of the identity of being to itself prior to any other proposition ${ }^{19}$. For example, according to the order of primacy, we have first the proposition "homo est homo", then "homo est animal rationale", then "homo est animal", followed by "homo est risibilis" and lastly "homo est album"20. We thus find two criteria which organize the these propositions: first, the identity of the subject with the predicate, and then the inclusion of the predicate in the definition of its subject. The

\footnotetext{
${ }^{17}$ Antonius Andreae, Quaestiones subtillissimae super duodecim libros Metaphysicae Aristotelis, ed. Venetiis 1491, q. 5 : Quantum ad secundum dico quod istud principium 'impossibile etc.' non est primum simpliciter, id est primo primum. Hoc probo sic. Quia illud principium cuius termini non sunt primo primi nec ultimo ultimi non est simpliciter primo primum. Sed hoc principium est huiusmodi. Ergo etc. Maior patet, quia ista duo sunt de ratione principii simpliciter primi, quod sit primo primum in essendo et ultimo ultimum in resoluendo. Minor probatur, et primo de termino subiecto quod est idem. Conceptus enim ille non est primo primus, cum sit resolubilis in duos alios conceptus, quorum unus est absolutus, alter respectiuus. Conceptus autem simul includens absolutum et respectiuum non est eque primus sicut conceptus inclusi in quos resoluitur. Iste autem conceptus idem ens est huiusmodi, quia li idem dicit conceptum respectiuum, li ens dicit conceptum absolutum uel saltem neutrum et indifferentem ad absolutum et respectiuum. Probatur etiam minor de termino predicato qui est esse et non esse. Ille autem conceptus est aggregatus ex affirmativo et negatiuo. Ergo est resolubilis. Ergo non est primo primus nec ultimo ultimus. Preterea nulla propositio modalis est primo prima, quia est resolubilis in aliam de inesse. Sed istud principium 'impossibile est, etc.' est propositio modalis. Ergo non est primo prima.
}

${ }^{18}$ It is interesting to note that the logician J. Lukasiewicz is known to have preferred the primacy of the identity principle to that of non-contradiction based on the same reasons. Cf. Lukasiewicz, J. and Wedin V. On the Principle of Contradiction in Aristotle. The Review of Metaphysics, n. 24-3, 1971, p.493.

${ }^{19}$ Antonius Andreae, Quaestiones subtillissimae super duodecim libros Metaphysicae Aristotelis, ed. Venetiis 1491, q. 5: Si ergo queratur quid est primum complexum simpliciter et primo primum, dico quod istud ens est ens. Istud enim principium habet terminus primo primos et ultimo ultimos et per consequens qui non sunt resolubiles in aliquos priores, immo omnis resolutio conceptuum stat ad conceptum entis ut ad simpliciter primum inter conceptus quiditationis.

${ }^{20}$ Antonius Andreae, Quaestiones subtillissimae super duodecim libros Metaphysicae Aristotelis, ed. Venetiis 1491, q. 5: Secundum dictum sit istud quod in propositionibus istis, siue affirmatiue, siue negatiue, est ordo in primitate. Nam quedam est primo prima, et quedam secundo prima, quedam tertio prima, et sic per ordinem et secundum quod plus uel minus accedunt uel recedunt ad propositionem primo primam. Exemplum in affirmatiuis: 'homo est homo' est primo prima, 'homo est animal rationale' est secundo prima, 'homo est animal' est tertio prima, 'homo est risibilis' est in quarto gradu, 'homo est album' est in quinto gradu etc. Patet enim quod iste habent ordinem in primitate si consideretur identitas extremorum. 
identity principle is, according to Andre, the only one that combines these two criteria.

Accordingly, Andre can re-qualify what Aristotle said about the principle of non-contradiction: he is first in relation to other logical principles, such as the principle of the excluded middle or "the whole is greater than the part". This is different from saying that the PNC is the very first one; because of its complexity, it is analyzable into other propositions. Andre tells us that the principle of non-contradiction is first in relation to any other principle except "omne ens est ens", so Aristotle's first principle is the "second first principle".

\section{"Ens est ens" in other $14^{\text {th }}$ century authors and Suarez}

Also in the 14th century we were able to identify other cases where the opinion according to which ens est ens is presented (and criticized) as an opposition to the primacy of the principle of non-contradiction: Jean de Baconthrope, Jean Buridan, and the one attributed to Nicolas of Autrecourt (we shall come back later to Autrecourt's text, of difficult interpretation). Moreover, Francisco Suarez reports this issue in his Disputationes Metaphysicae, where we can find interesting arguments to our debate.

John of Baconthorpe discusses the primacy of principles in his commentary to the Sentences $^{21}$ (which he read in Paris before 1318). According to him, the principle of non-contradiction is the first adequate object of complex intellection, whereas common being is the first object of simple intellection - which provides the foundation to the first principle. Indeed, the principle of non-contradiction is the proposition to which the intellect adheres in the most certain way without intermediaries, for it satisfies the three conditions of the first principles found in the fourth book of Metaphysics: (i) we cannot be wrong about it (circa ipsum non contingit mentiri), (ii) we must know him before any other knowledge (necesse est illud cognoscere quodcunque aliud cognoscentem), and (iii) it must come to mind from the knowledge of extremes (ex se veniat ad intellectum ex

\footnotetext{
${ }^{21}$ John of Baconthorpe, In I Sent., d. 3, q. 1, art. 1, ed. Cremonae 1618, p. 97b-98b. Cf. Goris, W. The Foundation of the Principle of Non-Contradiction. Some Remarks on the Medieval Transformation of Metaphysics. Documenti e studi sulla tradizione filosofica medieval, n. 22, 2011, p. 527-557.
} 
parte terminorum) ${ }^{22}$. Hence, as far as the identification of the first principle is concerned, Baconthorpe follows Aristotle.

Among the counter-arguments of this question is the opinion of Antoine Andre: the argument focuses more on the identity between subject and predicate than on the fact that the principle of identity is simpler than that of non-contradiction, on which Andre insists during his commentary.

No proposition is more known to us than that in which the same is predicated of itself. However, this is compatible with "being is being" and not "it is impossible that the same be and not be". So, etc. The minor is obvious, for in the negative [proposition] the same is never predicated of itself ${ }^{23}$.

In his response, Baconthorpe relies on the distinction between categorical and hypothetical propositions, saying that categorical prepositions could never be more known than a proposition in which the subject is identical to the predicate. However, a hypothetical proposition (as is the case with the principle of non-contradiction) is better known than a proposition maintaining the identity between its terms. The reason for the priority of hypothetical propositions is found in their connection with existence: whereas the categorical proposition "a man is" is not true if there are no men, the hypothetical proposition " it is impossible for a man to be and not to be at the same time" remains true whether men exist or not ${ }^{24}$. This answer is quite similar to that of Odonis, which is based on the distinction between "say more" and "say less" as a way of separating

\footnotetext{
${ }^{22}$ John of Baconthorpe, In I Sent., d. 3, q. 1, art. 1, ed. Cremonae 1618, p. 97 b : [...] dico quod ista complexa est notissima "impossibile est idem simul esse et non esse". Ab ipsa enim natus est intellectus noster primo moveri cum sit universalissima. Et huic intellectus noster firmius adhaeret et perfectius quia per pauciora media. Et isto modo oportet in proposito accipi primum perfectione, scilicet cui intellectus firmius adhaeret et immediatius. Et isto modo loquitur Philosophus per totum quartum Metaphysicae quia haec est prima notissima. Quod probo. Sunt enim ibi condiciones primi principii, scilicet quod circa ipsum non contingit mentiri, idest decipi vel errare secundum Commentatorem, et quod necesse est illud cognoscere quodcunque aliud cognoscentem et quod ex se veniat ad intellectum ex parte terminorum. Et assumit quod omnia ista conveniunt huic "impossibile est idem simul esse et non esse" et concludit quod est prima dignitatum et quod omnes aliae reducunt sua principia in hanc etc.

${ }^{23}$ John of Baconthorpe, In I Sent., d. 3, q. 1, art. 1, ed. Cremonae 1618, p. 98a: Item. Nulla propositio est nobis notior illa in qua idem de se praedicatur. Sed huic 'ens est ens' hoc convenit et huic 'impossibile est idem, etc.' hoc non convenit. Ergo etc. Minor patet quia in negativa idem nunquam de se praedicatur.

${ }^{24}$ John of Baconthorpe, In I Sent., d. 3, q. 1, art. 1, ed. Cremonae 1618, p. $98 \mathrm{~b}$ : Ad secundum cum dicitur 'nulla est notior ea, in qua idem de se etc.' Dico quod nulla cathegorica est notior illa in qua idem de se praedicatur, sed hipothetica bene est, quia haec 'homo est' negatur a multis homine non existente, sed haec 'impossibile est hominem simul esse et non esse' a nullo negatur sive homo sit, sive non.
} 
categorical propositions (including identity predictions) from hypothetical propositions (including the first principles) according to what they presuppose and its truth conditions.

John of Buridan, in the Lectura Erfordiensis of his questions to the Metaphysics, discusses the priority of the first principle. In the 16th question, he refutes Andre's opinion from a different distinction: to be more certain from the side of the thing (firmior ex parte rei) and to be more certain from the side of the intellect (firmior apud intellectum). As a result, negative propositions may be more certain for us, but not in reality. This leads him to say that the principle of non-contradiction is first from the side of the intellect. There is a common reasoning underling this response found in the previous critics: the more a proposition assumes, the more the intellect can consider him an object of doubt.

I consider that the [negative] proposition is more certain than the affirmative. For example, the proposition "no being is a non-being," or "no non-being is a being" is more certain than "being is being". And I do not say that the negative is more certain from the side of thing because any proposition that is the most certain and better known from the thing will be "affirmative". Nonetheless, the negative is more certain, that is, it is more believed by the intellect, so that the intellect can grasp less the opposite of the negative than the opposite of the affirmative ${ }^{25}$.

Beyond the Middle Ages, Francisco Suarez explicitly attributes this position to Antoine Andre. He criticizes it firmly by describing the proposition "omne ens est ens" as non-informative and unnecessary (nugatoria), consequently it does not figure as a principle of demonstrations and nothing is reducible to it:

The first sentence holds that the first principle does not correspond to the one we have drawn from Aristotle, but to the following: all being is a being (omne ens est ens). Such is the position of Antoine Andre, Book IV, Metaphysics, q. 5, who, referring to Aristotle, replies that he gives to this other principle the denomination of first among those that are commonly considered general, for example: the whole is greater than the part, etc.

\footnotetext{
${ }^{25}$ John of Buridan, Lectura Erfordiensis, ed. De Rijk, q. 16A, § 501, p.115 : Dico ergo prius dicta quod negativa videtur michi firmior quam affirmativa. Verbi gratia, ista propositio 'Nullum ens est non-ens' vel 'Nullum non-ens est ens' est firmior quam ista 'Ens est ens'. Et non dico quod negativa est firmior ex parte rei, quia omnio firmissima et certissima ex parte rei est <affirmativa > quod ens est ens, [...]. Sed negativa est firmior, idest firmius credita apud intellectum, ita quod intellectus minus posset capere oppositum negative quam oppositum affirmative [...].
} 
However, this author does not express himself in a coherent way, not even as regards his principles, for the formulation he proposes is tautological (nugatoria) and erroneous; in this sense, it is not assumed by any science as a demonstrative principle, being on the contrary foreign to all logic ${ }^{26}$.

As regards Nicolas of Autrecourt, the opinion according to which the principle ens est ens is the first principle (against PNC) was attributed to him by an anonymous Franciscan in a commentary to the Sentences of the 1350 , preserved in the Ms. Vat. lat. 986, f. 9rb:

\begin{abstract}
Against what was said before argues N. of Autrcourt's. He wants to prove that [this proposition] is first: 'being is being', or 'nothing is not something', because by virtue of this proposition any other proposition possesses evidence, including this one: 'of any one [being or not being and neither of both at the same time]'. And if you ask why the same cannot at the same time be and not be, the reason is that the same is identical to oneself at the highest point. It is known that this proposition is false 'man is not a man', because man is identical to himself at the highest point. Secondly, because nobody ever doubts that 'something is something'. Third, because this proposition is formed from the simplest terms, not from compound terms like that other proposition, which is disjunctive and copulative ${ }^{27}$.
\end{abstract}

It is striking that the arguments presented in favor of the primacy of "ens est ens" are essentially the same as Antoine Andre's, namely, the evidence of identity predication allied to the formal simplicity of the proposition, which is contrasted with the complexity of the principle of non-contradiction (combined with the excluded middle). Thus, similarly

\footnotetext{
${ }^{26}$ Francisco Suarez, Disputationes Metaphysicae, ed. Berton t. XXV, disp. III, sect. II § 4, p.112 : Prima sententia est non esse primum illud quod ex Aristotele retulimus, sed hoc, omne ens est ens. Ita tenet Antonius Andreas, IV Metaph., q. 5. Et ad Aristotelem respondet vocasse illud aliud primum principium inter ea quae circumferuntur ut generalia, ut sunt illa: Omne totum est, maius sua parte, etc. Sed hic auctor etiam in suis principiis non recte loquitur, quia illa propositio est identica et nugatoria; et ideo in nulla scientia sumitur ut principium demonstrationis, sed est extra omnem artem.

${ }^{27}$ Rijk. L. M. de. Nicholas of Autrecourt: His Correspondence with Master Giles and Bernard of Arezzo. Leiden: Brill, 1994, § 48, p. 201: Contra predicta arguit N. de Altricuria. Et vult probare quod hec est prima 'ens est ens' vel 'nichil $<$ non $>$ est aliquid, quia virtute huius omnis alia habet evidentiam, etiam ista 'De quolibet [esse vel non esse et de nullo simul].' Et si queritur quare idem non potest simul esse et non esse, ratio est quia idem est maxime sibi simile, quia scitur quod hec est falsa 'homo non est homo', quia homo est maxime sibi idem. Secundo quia ista numquam aliquis [aliquid Ms] dubitavit 'aliquid est aliquid'. Tertio quia ista est de terminis simplicibus et non de compositis sicut illa [ista Ms], que est disiunctiva et copulativa. About the manuscript see Tachau, K. H. French Theology in the Mid-Fourteenth Century: Vatican Latin 986 and Wrocaw, Milich F. 64, Archives d'Histoire Doctrinale et Littéraire du Moyen Age, n. 51, 1984, p. 41-80.
} 
to Andre, the anonymous author claims that the principle of noncontradiction presupposes the principle of identity, but he explains it differently: whereas for Andre the principle of non-contradiction depends on identity because of its analyzable complexity, the anonymous tells us that it is because man is identical with himself that he cannot be and not be at the same time. A question must be put to mind: did Nicolas of Autrecourt maintain the same position as Andre? We will come back to this issue shortly.

A similar position - but not quite equivalent - was attributed to Nicolas of Autrecourt in the documents concerning his condemnation ${ }^{28}$. According to the second article sent from Paris (from the list 'Articuli missi de Parisius ${ }^{29}$ ), Nicolas would have asserted that the principle 'si aliquid est, aliquid est' is the first principle. The article would come from the Principium of Autrecourt's commentary on the Sentences (text that we no longer possess $\left.{ }^{30}\right)$ :

This is the first principle, and not another: 'if something is, so it is' (quod hoc est primum principium et non aliud : 'si aliquid est, aliquid est').

This article could be interpreted as asserting, in accordance with the anonymous text transcribed above, that the identity principle is prior to the principle of non-contradiction - which would give further proof that Autrecourt indeed supported the Andre's position. The problem is that we find no trace of this thesis in the known writings of the maitre Lorrain. On the contrary, in his correspondence with the master of Arezzo, Autrecourt insists strongly on the foundational character of the principle of noncontradiction. Among his main theses is the assertion that all evidence and all certainty are reduced to that of the principle of non-contradiction, the only warranty of certainty.

We allow ourselves here to deal with this difficulty that suddenly crossed our reading of Nicolas of Autrecourt. The following considerations

\footnotetext{
${ }^{28}$ The trial of Nicolas of Autrecourt began in November 1340 in Avignon under Benedict XII and ended six years later with Clement VI, who addressed a doctrinal and disciplinary notification to the University of Paris. A year later, Nicolas made his retraction and publicly burned a part of his work. We rely on the excellent biographical study of $Z$. Kaluza, in Nicolas d'Autrécourt: Ami de la vérité, Histoire littéraire de la France 42. Paris: Boccard, 1995.

${ }^{29}$ L. M. Rijk. Nicholas of Autrecourt: His Correspondence with Master Giles and Bernard of Arezzo. Leiden: E.J. Brill, 1994, p. 200.
}

${ }^{30}$ Zenon, K. Nicolas d'Autrécourt: Ami de la vérité, p.108. 
intend to raise a hypothesis according to which Nicolas did not argue that the identity principle is prior in relation to the principle of noncontradiction (as did Antoine Andre), but this reading is actually a misunderstanding. We shall begin with a brief characterization of the theses of the maitre Lorrain concerning the primacy of PNC, and then we proceed to examine the reliability of the testimony of the two mentioned texts attributing to Autrecourt a position different from that which was transmitted to us by his work.

Nicolas opens the second letter to Bernard of Arezzo $^{31}$ by establishing the absolute primacy of the first principle. According to him, the principle "contradictoria non possunt simul esse vera" is doubly first ${ }^{32}$ : negatively - there is no principle that is prior to him -, and positively - it is prior to any other principle.

It is negative first because all certainty one possesses is reduced to this principle; it is positively first because it cannot be analyzed in other propositions $^{33}$. Being doubly first, it is absolutely first. The principle of non-contradiction is the foundation of Autrécourt's epistemology and the starting point of his theory of inferences. According to him, all certainty (except the certainty of faith) is reduced to that of the first principle ${ }^{34}$. Thus, for Nicholas, there are no degrees of evidence: a proposition is either per se nota and thus certain, or it cannot be object of certitude at all. For example, evidence based on the first principle does not allow us to pass from the knowledge of the existence of a thing to the knowledge of the existence of another thing, as this is not "analytical" 35 . The notion of substance is especially in danger: Nicholas maintains that it is not known

\footnotetext{
${ }^{31}$ Nicolas of Autrecourt, Correspondances, ed. De Rijk, p. 58-6o.

${ }^{32}$ Nicolas of Autrecourt, Correspondances, ed. De Rijk, p. 58, §2: [...] istud principium: 'Contradictoria non possunt simul esse vera'. Circa quod occurrunt duo. Primum est quod istud est primum principium, <primum $>$ negative exponendo: 'quo nihil est prius'. Secundum quod occurrit est quod istud est primum affirmative vel positive: 'quod est quocumque alio prius'.

33 Nicolas of Autrecourt, Correspondances, ed. De Rijk, p. 58, §3: Et hec duo probantur uno medio sic: Omnis certitudo a nobis habita resolvitur in istud principium. Et ipsum non resolvitur in aliquod aliud sicut conclusio in principium suum. Igitur sequitur quod ipsum est primum duplici primitate ».

${ }^{34}$ Nicolas of Autrecourt, Correspondances, ed. De Rijk, p. 62, §7: « Exepta certitude fidei, nulla est alia certitudo nisi certitudo primi principii, vel que in primum principium potes resilvi.

${ }^{35}$ Nicolas of Autrecourt, Correspondances, ed. De Rijk, p. 64, §11: Ex eo quod aliqua res est cognita esse, non potest evidenter, evidentia reducta in primum principium, vel in certitudinem primi principii, inferri quod alia res sit.
} 
with certainty, and that even Aristotle knew no substance apart from his own soul ${ }^{36}$.

As a result, we find in Nicolas of Autrecourt a rigorous discussion on the criteria of evidence whose foundationalism seems to lead him to a kind of skepticism regarding our ability to know things with confidence. It is not astonishing that these polemical theses were considered unorthodox and resulted in public condemnation. What remains surprising for us is the fact that it was attributed to Nicolas the position according to which the principle of non-contradiction is not absolutely first. It seems problematic to conclude that both opinions were hold simultaneously by Autrecourt, that is, the Principle of non-contradiction is the sole source of certitude and that it is less evident than the principle according to which being is identical to itself ${ }^{37}$. We remain with two options: (i) Autrecourt changed his position or (ii) he never did really sustain that the identity principle is prior to PNC. We intend to show that the latter is more likely to be the case.

To hold that Nicolas of Autrecourt sustained the primacy of the identity principle implies two theses:

- The three textual evidences are equally reliable: the second letter from Nicolas to Bernard of Arezzo, the anonymous extract from the

\footnotetext{
${ }^{36}$ Nicolas of Autrecourt, Correspondances, ed. De Rijk, p. 72, §22: infero quod numquam Ariatotiles habuit notitiam evidentem de aliqua substantia alia ab anima sua. Cf. Robert. A., "Jamais Aristote n'a eu de connaissance d'une substance: Nicolas d'Autrécourt en contexte », in Caroti, S. et Grellard, C (éds.), Nicolas d'Autrécourt et la Faculté des Arts de Paris (1317-1340): actes du colloque de Paris, 19-21 Mai 2005. Cesena: Stilgraf, 2006, p. 113-152.

${ }^{37}$ Our solution to this difficulty drives us to criticize C. Grellard's position where he too must account for the problem we have just encountered. In seeking to reconcile Autrécourt's Letters with the extracts quoted above (the text of the anonymous Franciscan and the condemned article) Grellard proposes an interpretation according to which the principle of identity is the "ontological variant" of the epistemological principle of non-contradiction. The two principles would be complementary and would both pose the possibility conditions for meaningful predication. The principle of identity would be a "positive facet" of the negative principle of non-contradiction. As consequence, this complementary identity is the foundation for the impossibility of contradiction, for it is because a thing is identical with itself that it cannot be and not be at the same time. However, it seems problematic to us to understand the principle of identity as the ontological variant of the principle of non-contradiction. In our view, this thesis presents a double difficulty: one of a purely logical nature, the other concerning the possibility of its conception in a certain historical context. First, assuming that principle $a$ is reducible to a more fundamental principle $b$, then necessarily there are two principles, thus it is not accurate to speak of two versions of the same principle. Moreover, if we are allowed to make a general claim about the understanding of the principle of non-contradiction by the medieval thinkers, we would say that the epistemological and ontological levels were not seen as separate. In other words, for the medieval the impossibility of contradiction in things and the impossibility of contradiction in meaningful discourse are always expressed by the same principle. Cf. Grellard, C. Croire et savoir: les principes de la connaissance selon Nicolas D'Autrécourt. Paris: Vrin, 2005, p. 69-70; Cf. also Grellard's introduction in Nicolas d'Autrécourt, Correspondance, Articles Condamnés. Paris: J. Vrin, 2001. p. 31-32.
} 
manuscript Vat. Lat. 986 and the second convicted article received from Paris.

- The principle opposed to the primacy of the principle of noncontradiction in the anonymous extract ('ens est ens') is equivalent to the principle present in the condemned article (si aliquid est, aliquid est). That is to say, both texts speak of the identity principle.

Regarding the second point, it seems to us that the propositions "ens est ens" and "si aliquid est, aliquid est" are not equivalent. We have already seen the various arguments that have been advanced since Antoine Andre to support the primacy of ens est ens over PNC, namely, (i) the fact that it expresses the evident identity between the subject and the predicate (for it is immediately included in the subject), and (ii) the fact that it is simpler in its fomulation. Now, "si aliquid est, aliquid est" does not fulfill any of these conditions: this proposition does not express the identity between the subject and the predicate, and it has a complex formulation (at least more complex than ens est ens). Moreover, "something exists" or "there is something" is clearly part of an existence judgment, which is not normally attributed to the identity principle.

It is interesting to note that the principle "si aliquid est, aliquid est" resembles much more the first principle maintained by Leon of Padua against precisely the principle of non-contradiction of Autrecourt. In his Decas logicas (text from the late 1350 s preserved in the Edingurgh manuscript, University Library, cod. 133) Padua criticizes two moderni, namely, Ockham and Autrdcourt. The two philosophers are not explicitly mentioned, but long extracts from their works are quoted ${ }^{38}$. In the folios $28 \mathrm{v}-29 \mathrm{r}$ of his logical treatise, Padua opposes to the double primacy of the principle of non-contradiction the primacy of a principle that he calls the first protosophical principle (!), namely, "aliquid est". The fact that "one thing cannot be and not be at the same time" would be dependent on the evidence that "there is something" - a certainty we owe to our inner experience. It seems that the certitude of one's own existence (a cogitolike certitude) must be prior to PNC. The principle of non-contradiction adds to the former certainty the distinctions between true and false, and therefore the metaphysical principle is posterior to the protosophical

\footnotetext{
${ }^{38}$ The quotations from the second letter of Nicolas of Autrécourt to Bernard d'Arezzo are so long that the editor De Rijk considers Padue's text as an additional source of Autrécourt's text. Cf. De Rijk, Nicholas of Autrecourt: His Correspondence with Master Giles and Bernard of Arezzo. Leiden: E.J. Brill, 1994, p. 15-24.
} 
principle $^{39}$. We do not intend to further discuss this difficult text, but we would like to stress the fact that Leon of Padue criticizes the double primacy Nicolas of Autrecourt accords to the PNC. This joins my hypothesis according to which there is no other principle prior to PNC in Autrecourt.

We would still like to question the precision of certain texts elaborated by Autrecourt's committee of censors, especially the list of articles sent from Paris. According to Kaluza in his masterly study on Autrecourt's life, the commission responsible for his trial had knowledge of all his works: Letters, Exigit ordo, the philosophical teaching from his principium in the Arts Faculty, his 1330 s course on the Politics of Aristotle, and his reading on Sentences ${ }^{40}$. However, the same commission did not necessarily have all these documents in front of them. For example, Kaluza offers evidences that the censors did not know all the chapters of the Exigit ordo: while they knew well the preface and the first book, they would have had some information on the remaining chapters through a compilation of the articles made in Paris and sent to Avignon ${ }^{41}$.

Kaluza asserts that certain theses of the Exigit ordo and, more generally, the theses on the oral teaching of Autrecourt were known either by rumor or by testimony, all being an echo of his philosophical teaching ${ }^{42}$. It is further explained to us that "the list drawn from the Exigit ordo does not correspond to what Nicolas had written: he thought the hypotheses (imaginationes) which he examined, whereas the judge transformed them indistinctly into affirmations"43, and that "Nicolas of Autrecourt was obliged to retract several dozen theses, the accuracy of which he never admitted the accuracy, and the inquisitor never succeeded in proving

\footnotetext{
${ }^{39}$ Léon de Padue, Decas Logicas, fol. 28v-29r: Apud recte sapientes nil manifestius qual quod aliquid est. Ex quo evidenter inferunt falsum esse nil esse, per hoc quod impossibile est idem eidem simul inesse et non inesse ad idem, secundum idem, simul et in eodem tempore. [...] quod autem constet ex proprio testimonio aliquid esse docet experientia intrinseca nobis dumque tale iudicium fuerit, eo ipso est aliquid.Esse tamen sic aliquid quod eius contradictorium non sit verum, habetur ex principio methaphisico, quo ponitur contradictoria non posse simul esse vera. Ultra itaque primum principium protosophye addit principium methaphisicum discretionem veri a falso eorumque incompossibilitatem, si contradictoria fuerint. Quoted in L. M. Rijk. Nicholas of Autrecourt: His Correspondence with Master Giles and Bernard of Arezzo. Leiden: E.J. Brill, 1994, p. 16, n. 51. See also Bottin, F. « La polemica contro I moderni loyci (G. di Ockham e N. di Autrecourt) nella Decas Loyca di Leonino da Padova ». Medioevo 4, 1978, p. 136-140.

$4^{40}$ Kaluza, Nicolas d'Autrécourt: Ami de la vérité, p. 114.

${ }^{41}$ Kaluza, Nicolas d'Autrécourt: Ami de la vérité, p. 118-9.

${ }^{42}$ Kaluza, Nicolas d'Autrécourt: Ami de la vérité, p. 116-117.

${ }^{43}$ Kaluza, Nicolas d'Autrécourt: Ami de la vérité, p. 115.
} 
otherwise. By making a complete retraction, Nicolas of Autrecourt submitted himself in order to not finish his life in a pontifical prison" ${ }^{44}$ Among the four lists of theses that Nicolas had to retract -the four errors, the Ve Michi document, the articles sent from Paris and the articles extracted from the Exigit ordo - only the first two were admitted by the maître Lorrain ${ }^{45}$.

Given these historical considerations, what can we say about the accuracy of the articles sent from Paris concerning his Autrecourt's writings? More precisely, can we rely on the attribution of the second article (according to which the first principle is that which says "si aliquid est, aliquid est") to him? We must be cautious about the possible distortions introduced by the examiners of the Paris commission. It seems imperative to admit the possibility that some of these articles were badly copied and taken out from their context. It seems to us therefore more appropriate to examine Autrecourt's position by dropping the condemned article.

Also, we have reasons to state that the thesis of the anonymous text according to which (i) the identity principle is prior to the principle of noncontradiction, and the thesis of the second letter to Bernard claiming that (ii) the PNC principle is doubly first are incompatible. Unless one wishes to introduce a distinction similar to that of Antoine Andre (according to which the principle of non-contradiction is first while that of identity is absolutely first), one must choose one of the two theses. We propose two alternative hypotheses:

- Either Nicolas affirmed the theses (i) and (ii) in different moments by changing his opinion.

- Either Nicolas has never affirmed the thesis (i).

The hypothesis that Nicolas has changed his opinion is not eliminated, but is not very attractive, for the commentary on the Sentences and the letters to Bernard were written at the same time: we know that Nicolas read the sentences in Paris during the academic year of $1335^{-6}$ or 1336-7 and Kaluza proposes the same period for the composition of the

\footnotetext{
${ }^{44}$ Kaluza, Nicolas d'Autrécourt: Ami de la vérité, p. 121.

${ }^{45}$ Cf. L. M. Rijk. Nicholas of Autrecourt: His Correspondence with Master Giles and Bernard of Arezzo. Leiden: E.J. Brill, 1994, “Appendix B”, p. 167-207.
} 
Letters ${ }^{46}$. Despite the testimony of the anonymous extract, the second thesis still seems to us more sustainable. We have seen above that Antoine Andre's position was well known and often quoted (and then refuted) as an argument contrary to the primacy of the principle of non-contradiction. It is thus acceptable to ask whether Autrecourt would have done the same thing, that is, quoted Andre's argumentation without sanctioning it. Would a poor reading on the part of our anonymous Franciscan be at the origin of this attribution? This alternative is not negligible. Therefore, we believe that these considerations are sufficiently plausible to weaken (if not to refute) the explanation according to which Nicolas of Autrecourt supported at the same time, or in different moments, the primacy of the identity principle in detriment of the principle of non-contradiction.

\section{Conclusion}

This discussion allows us to discover the originality of the debates on the first principles and the plurality of opinions in the fourteenth century. Indeed, this context is marked by a detachment of Aristotle's text and by a reflection on the conditions of evidence and the starting point of certain knowledge. Despite realizing in the literature an alternative logical candidate to the absolute firs principle - Antoine Andre's identity principle - the hegemony of Aristotle's principle of non-contradiction, often coupled with the excluded middle, persisted in a constant. This is not only an authority issue, but we could detect a quarrel among the given reasons for primacy: as some searched for strictly formal primacy (the complexity of the proposition issue), others saw in the PNC the expression of the logical conditions for intelligibility and signification. Odonis showed he was attentive to this distinction and formulated an adequate refutation of Andre's principle. The role of PNC in Nicolas of Autrecourt's work is especially interesting insofar as it confers a major importance to the certainty of the first principle and to the logical mechanisms that make possible the transfer of certainty to other propositions. Like Autrecourt, Odonis puts great importance on the investigation of the primacy of the first principles and at the origin of their absolute certainty as a central

\footnotetext{
${ }^{4} \mathrm{Cf}$. Kaluza, Z. Serbi un sasso il nome: une inscription de San Gimignano et la rencontre entre Bernard d'Arezzo et Nicolas d'Autrécourt, in: Mojsisch, B. et Pluta O (eds.), Historia philosophiae medii aevi. Studien zur Geschichte der Philosophie des Mittelalters, Amsterdam: B.R. Grüner, 1991, p.451; 462-4.
} 
996 | Veritas | Porto Alegre, v. 63, n. 3, set.-dez. 2018, p. 976-997

feature of their thought. For these philosophers, the subordination of any other source of certainty to the necessity of non-contradiction reveals a valorization of logical science.

\section{Bibliography}

Ancient and Medieval texts:

ANTOINE ANDRE, Questiones Super Duodecim Libros Methaphysice. Venetiis: M. Boneti Locatelli, 1491.

ARISTOTLE, Metaphysics. edited by W. D. Ross. Oxford: Clarendon Press, 1958.

JOHN OF BACONTHORPE. Quaestiones in Quatuor Libros Sententiarum, Et Quodlibetales. Ed. Cremonae, S.L: s.n, 1618.

JOHN OF BURIDAN. Lectura Erfordiensis in 1.-6. Metaphysicam Together with the 15thCentury Abbreviatio Caminensis. edited by L. M. Rijk, Turnhout: Brepols, 2008.

GIREALDUS ODONIS O.f.m. Opera Philosophica: vol. 1. edited by L. M. de Rijk. Leiden: Brill, 1997.

FRANCISCO SUARES, Disputationes Metaphysicae, t. XXV of Opera Omnia, edited by Charles Berton. Paris: Vives, 1856-61. Reprinted Hildesheim: G. Olms, 2009.

Secondary bibliography:

BOTTIN, F. « La polemica contro I moderni loyci (G. di Ockham e N. di Autrecourt) nella Decas Loyca di Leonino da Padova ». Medioevo 4, 1978.

GRELLARD, C. Croire et savoir: les principes de la connaissance selon Nicolas D'Autrécourt. Paris: Vrin, 2005.

. Nicolas d'Autrécourt, Correspondance, Articles Condamnés. Paris: J. Vrin, 2001.

GORIS, W. The Foundation of the Principle of Non-Contradiction. Some Remarks on the Medieval Transformation of Metaphysics. Documenti e studi sulla tradizione filosofica medieval, n. 22, 2011

KALUZA, Z. Nicolas d'Autrécourt: Ami de la vérité, Histoire littéraire de la France 42. Paris: Boccard, 1995 .

. Serbi un sasso il nome: une inscription de San Gimignano et la rencontre entre Bernard d'Arezzo et Nicolas d'Autrécourt, in: Mojsisch, B. et Pluta O (eds.), Historia philosophiae medii aevi. Studien zur Geschichte der Philosophie des Mittelalters, Amsterdam: B.R. Grüner, 1991.

LUKASIEWICZ, J. On the Principle of Contradiction in Aristotle. The Review of Metaphysics, n. 24-3, 1971. 
PINI, G. Scotistic Aristotelianism: Antonius Andreas' Expositio and Quaestiones on the Metaphysics, in: Via Scoti. Atti del Congresso Scotistico internazionale, Roma 9-11 marzo 1993, Sileo, L. (éd.) vol. 1, Roma: Edizioni del Pontificio Ateneo Antonianum, 1995 .

De RIJK. L. M. Nicholas of Autrecourt: His Correspondence with Master Giles and Bernard of Arezzo. Leiden: E.J. Brill, 1994.

ROBERT. A. "Jamais Aristote n'a eu de connaissance d'une substance: Nicolas d'Autrécourt en contexte », in Caroti, S. et Grellard, C (éds.), Nicolas d'Autrécourt et la Faculté des Arts de Paris (1317-1340): actes du colloque de Paris, 19-21 Mai 2005. Cesena: Stilgraf, 2006.

TACHAU, K. H. French Theology in the Mid-Fourteenth Century: Vatican Latin 986 and Wrocaw, Milich F. 64, Archives d'Histoire Doctrinale et Littéraire du Moyen Age, n. 51,1984 . 